Biol. Stud. 2009: 3(1); 105-114 • DOI: https://doi.org/10.30970/sbi.0301.019

www.http://publications.Inu.edu.ua/journals/index.php/biology

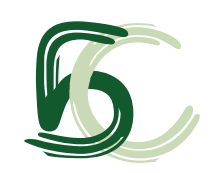

УДК 582.32.581.5

ДО 85-РІЧНОГО ЮВІЛЕЮ КУПАВИ ОСТАПІВНИ УЛИЧНОЇ

О. В. Лобачевська', З. І. Мамчур², Т. Г. Кулик

${ }^{1}$ /нститут екології Карпат, вул. Стефраника, 11, Львів 79000, Україна

e-mail: morphogenesis@mail.Iviv.ua

${ }^{2}$ Львівський національний університет імені Івана Франка вул. Грушевського, 4, Львів 79005, Україна

${ }^{3}$ Державний природознавчий музей НАН України,

вул. Театральна, 18, Львів 79008, Україна

У статті, присвяченій 85-річчю українського ботаніка-бріолога Купави Остапівни Уличної, наведено біографічні матеріали, розглянуто головні напрями науководослідної діяльності та подано список наукових праць видатної дослідниці.

Ключові слова: Улична Купава Остапівна, бріолог, мохоподібні, гербарій, бріофлора Українських Карпат, форми росту, мохові синузії.

Купава Остапівна Улична - видатний український ботанік, одна із засновниць львівської бріологічної школи. Народилася 15 січня 1924 р. у селі Колодисте Уманського району Черкаської області.

Батько - Остап Гнатович Уличний - родом зі села Погорільці Перемишлянського району Львівської області. Навчаючись у гімназії, він організував гурток Наукового товариства імені Шевченка, який розігнали вже після першого засідання, а хлопця вигнали з гімназії та заарештували. Після закінчення курсів бухгалтерів, організованих для допомоги українцям 3 ініціативи НТШ, Остап Уличний працював у підприємця бухгалтером. 3 початком Першої світової війни його забрали до австрійської армії. Після боїв на г. Маківці він потрапив у полон і опинився в Росії. Працював робітником під Москвою.

Мати Купави Остапівни - Тетяна Іванівна, 1888 р. народження, - після нещасливого першого шлюбу з козаком із Кубані працювала

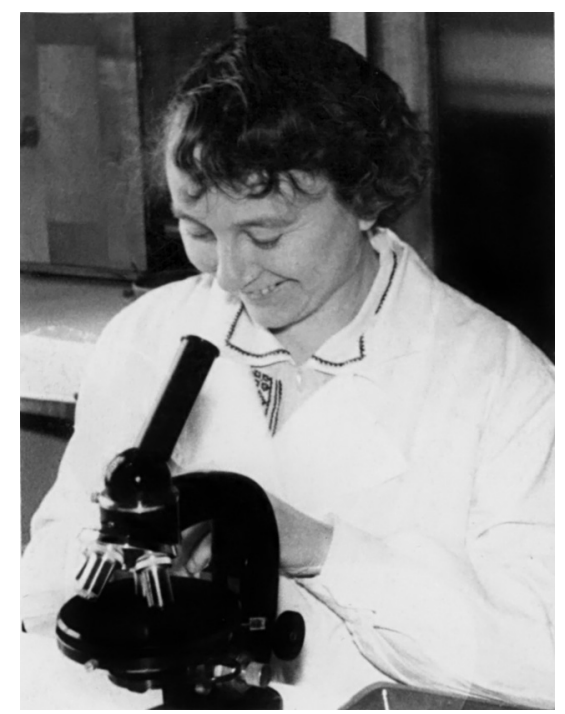


хатньою робітницею у сім'ї священика під Москвою. Познайомившись, молоді люди через певний час вирішили поєднати свої долі. 3 початком революції 1917 р. Остап Уличний повернувся в Україну, де протягом 1919-1920 працював у видавництві НТШ. Тоді ж до нього з Росії приїхала дружина, народилася донька Мирослава.

Сім'я Уличних завжди була в курсі подій українського культурного життя: до них часто навідувалися Павло Тичина, Микола Зеров. Під час громадянської війни почалися переслідування українських патріотів, батька схопили військові генерала Муравйова і хотіли розстріляти, але завдяки благанням дружини-росіянки відпустили. Сім'я переїхала у село Колодисте (неофіційна назва - село Рижачка), що під Уманню. Тут народилася друга донька - Купава. Через постійні переслідування сім'я потрапляє на Кубань, а після колективізації 1929 р. знову повертається в Україну, де поселяється в с. Згурівка на Харківщині. Там Купава Улична навчалася з 1 по 9 клас. Зі спогадами дитинства тісно пов'язані прогулянки по Кочубеївському парку у Згурівці. Із зібраних у парку рослин дівчина офрормила свій перший гербарій. Спонукало до цього, мабуть, і те, що батько якось привіз із Інституту ботаніки „Визначник рослин” В. Талієва.

У страшні часи голодомору сім'я дивом вижила, хоча надії на порятунок залишалося мало: тіло розпухало, особливо руки й ноги, рухатися було майже неможливо. Напевно, саме роки голоду підірвали й так не дуже міцне здоров'я молодшої доньки Купави, проте загартували ії̈ силу духу та національну свідомість.

Батька знову заарештували і засудили за те, що говорив про організований голод в Україні. Спочатку писав листи з Дніпропетровської тюрми, згодом із Караганди. Останню телеграму від батька сім'я одержала з Колими...

У тяжкі воєнні роки мати з доньками переїхала у рідне село батька, на Галичину. У м. Перемишлянах Купава трохи працювала секретаркою у райземвідділі. У 1944 р. пішла на підготовчі курси Львівського державного університету, після яких вступила на біологічний фракультет ЛДУ і навчалася там до 1950 р.

Першу курсову роботу про птахів Закарпаття студентка виконала під керівництвом професора Ф. Страутмана. Великий вплив на формування світогляду К. Уличної як молодого науковця мав завідувач кафедри морфології та систематики рослин, відомий український вчений, бріолог зі світовим іменем, профеесор Андрій Созонтович Лазаренко, який відразу зауважив здібну студентку і залучив її до вивчення цікавої групи рослин - мохоподібних. Яскравими спогадами для К. Уличної були наукові експедиції з відомими ботаніками Д. Зеровим і М. Поповим. Перший рік після закінчення університету вона вчителювала у смт Ланівці Тернопільської області.

У 1951 р. Купава Улична вступила до аспірантури Інституту агробіології АН УРСР. Професор А.С. Лазаренко, який тоді керував Інститутом, організував групу науковців для вивчення бріофлори Карпат. Купава Остапівна обрала для дослідження Буковинські Карпати (Чернівецька область), а в 1954 р. захистила кандидатську дисертацію на тему „Аналіз бріофлори Чернівецької області".

У 1954-1955 роках вона працювала на посаді заступника директора 3 наукової роботи ботанічного саду Львівського державного університету, у 1955- 


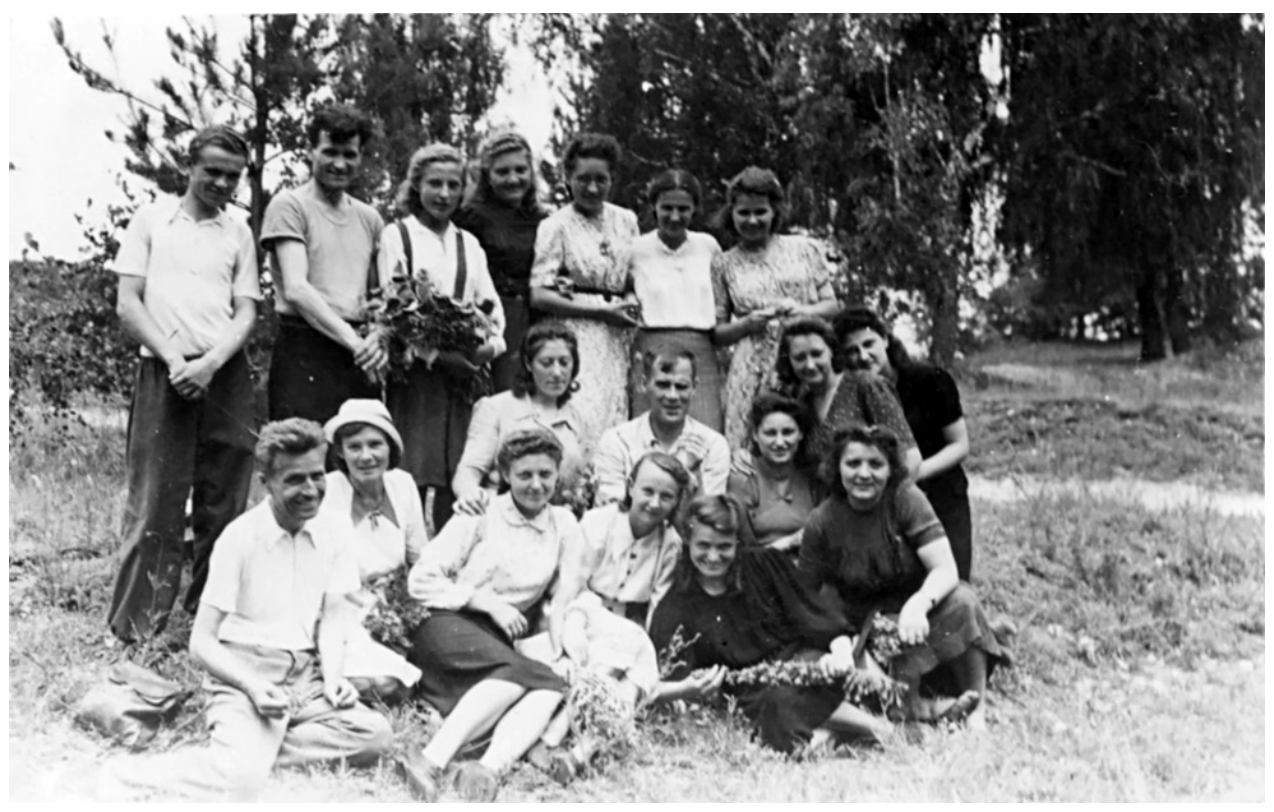

Львів, Чортова Скеля, червень 1947 р.

К. О. Улична (у першому ряду четверта зліва) з проф. А. С. Лазаренком і доц. І. В. Боговиком

1957 роках - старшим науковим співробітником. Нинішні колекції, що становлять фонд відділу культурної фрлори й озеленення університету, започаткувала Купава Остапівна, збираючи багаторічні й однорічні декоративні рослини. А весь свій вільний час присвячувала дослідженню мохоподібних.

У 1957 р. на конкурсній основі її обрали молодшим науковим співробітником відділу ботаніки Львівського науково-природничого музею АН УРСР. Відділом у цей час керував професор Андрій Созонтович Лазаренко. Згодом цей відділ стане окремим структурним підрозділом Львівського відділення Інституту ботаніки ім. М.Г. Холодного, там Купава Улична працювала до 1967 року. У наступні роки (1967-1970) була асистентом кафедри біології Львівського медичного інституту.

Найосновніші віхи наукової діяльності Купави Остапівни пов'язані з Державним природознавчим музеєм АН УРСР, де вона працювала вченим секретарем (1970-1979).

У 1979 р. К. О. Улична вийшла на пенсію, продовжуючи активну наукову діяльність. Разом із молодшими колегами проводила цікаві дослідження, публікувала отримані результати.

Перші наукові праці К. О. Уличної [2, 3, 5] присвячені вивченню бріофлори Буковинських Карпат. Флористичний список області, в котрому було 272 види, відобразив досить повну картину видового складу і географічного розподілу бріфлори й історії її розвитку. Вперше подано 157 видів для Чернівецької області, 2 види (Coscinodon cribrosus та Eurhynchium angustirete) - для бріофлори СРСР.

Численні експедиції у Карпати дали можливість зібрати розмаїтий і цінний матеріал, який значно збагатив бріологічний гербарій, ставши основою для 
багатьох наукових праць, у яких дослідниця описує багато нових і цікавих для України видів мохів. У 1956 р. з'явилося повідомлення [4] про знахідку гукерії блискучої в Східних Карпатах (околиці м. Сколе). Нове місцевиростання Hookeria lucens - представника тропічної родини і роду - було другим для фрлори УРСР і третім для фолори СРСР. На підставі аналізу поширення реліктових третинних видів К. О. Улична висловила думку, що в Карпатах гукерія блискуча не $є$ післяльодовиковим мігрантом з океанічних притулків Західної Європи, а гірським видом з високодиз'юнктивним ареалом, що пережив льодовиковий період саме в Карпатах. Факт знахідок нових видів для бріофлори Українських Карпат і рідкісних видів для України цікавий у зв'язку з питанням про реліктову бріофлору, особливо про тропогенні третинні релікти. Багато праці присвятила К. О. Улична [1, 4, 21, 26, $27,34,71]$ вивченню поширення й життєвості рідкісних видів, детальному картуванню їх місцевиростань, зокрема представників стародавньої родини Seligeriaceae на заході України, що становить значний інтерес для дослідження флорогенезу мохоподібних.

Детальне дослідження бріофлори Чорногори дало змогу не лише уточнити й визначити основні історичні етапи поширення мохоподібних, а й пов'язати його із загальним розвитком рослинного покриву на цій території [18, 36, 62]. К. Улична зібрала величезні та цінні гербарні колекції мохоподібних під час бріологічних експедицій і геоботанічних обстежень Українських Карпат (Бескиди, Горгани, Чорногора, Чивчино-Гринявські гори), які нині зберігаються в гербарії Державного природознавчого музею НАН України. Згодом вона провела розгорнуті фрлористичні дослідження на Передкарпатті та Поділлі, що значно поповнили бріологічні фронди музею.

Гербарій печіночних і сфагнових мохів Державного природознавчого музею був закладений Купавою Остапівною у 1960-1961 роках з матеріалів власного збору, а також із переданих академіком АН УРСР Д. К. Зеровим зразків гербарію Інституту ботаніки АН УРСР. Упродовж 1970-1976 років К. О. Улична зібрала значні мікологічні матеріали, що виділені в окрему колекцію (Mycophyta) Гербарію несудинних рослин. У 1970-1971 роках вчена розпочала критичний перегляд, упорядкування, опрацювання невизначених матеріалів, інвентаризацію та критичний перегляд окремих родин. Частину гербарію становлять ексикати і дублетні зразки, прислані дослідниці із бріологічних гербаріїв різних міст України та зарубіжжя, переважно з Фінляндії (Т. Копонен і співробітники). Завдяки глибоким знанням бріофрлори, великій і наполегливій праці науковця 3 колекціями бріологічного гербарію музею, ця робота завершилася підготовкою матеріалів каталогізації, опублікованих частинами у випусках видання „Каталог музейних фондів. Державний природознавчий музей АН УРСР”. Перша частина каталогу листяних мохів [42] - результат опрацювання гербарію родини дікранових. Критично переглянуті матеріали родин андреєвих, тетрафісових, політріхових, буксбаумієвих, дифісцієвих, бріоксиорієвих, зелігерієвих, поттієвих (без роду Tortula), гріммієвих, ефемерових і трьох родів брієвих (лептобрій, мніобрій та плагіобрій) включено до другої частини [43]. У третій частині каталогу [45] представлено каталогізаційні матеріали родин левкобрієвих і фіссиденсових.

Купава Остапівна Улична - невтомна дослідниця. Вона не обмежилася вивченням фрлористичного і систематичного складу бріофлори Українських Карпат.

ISSN 1996-4536 • Біологічні Студії / Studia Biologica • 2009 • Том 3/№1 • С. 105-114 
Вона з'ясувала і закономірності поширення мохоподібних у рослинних угрупованнях [17]. Досліджуючи участь мохоподібних у рослинному покриві та сукцесійних рядах рослинності Карпат, К. О. Улична $[8,22,24,30]$ виділила бріосинузії за особливостями форм росту, зумовленими адаптивними властивостями бріофітів і екологічними умовами середовища. Для з'ясування еколого-ценотичних зв'язків у фрітоценозах приділила багато уваги описам мохових синузій, їхній структурі, закономірностям формування та взаємозв'язкам їхніх компонентів [5, 6].

У моховій рослинності високогір'я Карпат К. О. Улична $[22,24]$ виділила такі типи форм росту: відкрита дернинка, справжня дернинка, подушкоподібна дернинка, кільчасто-галузиста дернинка, справжня подушка, дерниста подушка, таломний килим, плоский килим, вертикально-галузистий килим, крокуюча фрорма килима, розгалужено-гіллясте плетиво, пірчасто-галузисте плетиво, дендроїдна фрорма. В основу класифікації фрорм росту покладені концепція К. Гаймінгама та Е. Робертсона, Х. Мойзеля і власні спостереження Купави Остапівни за ростом та поновленням окремих листкостеблових пагонів і цілих дернинок упродовж їхнього існування. Вона вважає, що розподіл форм росту визначається насамперед умовами зволоження, трофністю угруповання та режимом освітлення, ценотичні фрактори діють тільки опосередковано через зміну згаданих умов. Для дослідження фрлористичних і геоботанічних показників К. О. Улична $[65,66]$ вперше модифікувала метод визначення частоти трапляння та проективного покриття мохоподібних в епіфітних обростаннях з використанням целофанових плівок.

Великого значення надавала К. О. Улична екологічним дослідженням мохів, оскільки вони часто утворюють суцільний моховий ярус, який має певний вплив на динамічні процеси в рослинному покриві, виконує важливу ґрунтозахисну та водозатримну функції. Як приклад ґрунтовних екологічних досліджень слід навести праці [12-14], присвяченні вивченню віку дернинок двох едифікаторних мохів високогір'я Карпат Polytrichum commune і Hylocomium splendens у різних рослинних угрупованнях Чорногори, а також залежності приросту стебла моху від його віку.

Як систематик дослідниця з успіхом опрацювала такі складні родини, як Dicranaceae (роди Dicranum та Dicranella) та Seligeriaceae [11, 32, 44, 61, 71]. Базуючись на багатому досвіді, вона зробила узагальнення анатомо-морфологічних особливостей гаметофріту і внутрішньовидової морфологічної дивергенції мохів, пов'язаної з різними умовами місцевиростання [48, 50, 53, 56, 59, 60]. Детально дослідивши закономірності проявів морфологічної мінливості протягом онтогенезу мохів, К. О. Улична істотно розширила уявлення про вид, його морфологічну дискретність і зв'язки з близькими видами.

Творчий ентузіазм завжди спонукав Купаву Остапівну до пошуку нових підходів і напрямів, нових методів дослідження. К. О. Улична - чудовий експериментатор. Завдяки порівняно нескладному культивуванню в лабораторних умовах і швидкому завершенню життєвого циклу мохів, вона детально дослідила явище міжвидової гібридизації між близькими клейстокарпними і стегокарпними видами родів Phascum і Pottia [41] та Tortula canescens і T. muralis [69]. Порівняння батьківських і похідних форм гібридного диплоїдного покоління дало змогу виявити активність геномів обох вихідних видів. Слід зазначити, що Купава Остапівна велику увагу 
приділяла не лише експериментальному дослідженню гібридизаційних процесів і утворенню апогамних структур [19, 20], а й їх значенню для еволюції мохів. Крім цього, вона визначала вплив умов виростання як одного з багатьох факторів формування рослинних комплексів. На підставі детального анатомо-морфологічного дослідження гербарних зразків Fissidens cristatus [51] дослідниця встановила зв'язок морфологічної мінливості з екологічною приуроченістю виду та виділила дві фрорми (f. cristatus i f. micronatus), які виникли внаслідок внутрішньовидової дивергенції під впливом різних умов місцезростань.

Коло питань, які цікавлять Купаву Остапівну, охоплюють різноманітні аспекти бріології. Її наукові праці відзначаються актуальністю та важливістю розглянутих проблем, широко відомі серед бріологів у світі. Вона заслужено користується великим авторитетом і глибокою повагою. Вагомий внесок К. О. Улична зробила у підготовку та виховання наукових кадрів. Вона щедро ділиться невичерпним досвідом і знаннями зі своїми молодшими колегами й аспірантами (Т. Г. Кулик, С. В. Гапон, 3. І. Мамчур). Учнями Купави Остапівни вважають себе науковці відділу екоморфогенезу рослин Інституту екології Карпат НАН України: О. В. Лобачевська, Я. Д. Хоркавців, І. С. Данилків. ІІї невичерпна працьовитість і принциповість $€$ кращим прикладом наукового дерзання, цілеспрямованої праці, справжньої любові до науки і природи.

Сердечно вітаємо Вас, дорога Купаво Остапівно, зі славним ювілеєм!

Бажаємо доброго здоров'я і творчих сил! Хай не втомлюються Ваша душа і Ваш розум!

\section{Список друкованих праць К. О. Уличної}

1. Улычна К.О. Светящийся мох в Карпатах. Природа, 1954; 6: 118-119.

2. Улычна К.О. Анализ бриофлоры Черновицкой области: Автореферат диссертации кандидата биологических наук. К., 1955. 14 с.

3. Улична К.О. Зведений список листяних мохів Чернівецької області. Наукові записки Львівського науково-природознавчого музею АН УРСР, 1956; 5: 126-144.

4. Лазаренко А.С., Улична К.О. Гукерія блискуча в Східних Карпатах. Наукові записки Львівського науково-природознавчого музею АН УРСР, 1956; 5: 145-148.

5. Улична К.О. Мохові синузії Буковинських Карпат. Наукові записки Львівського науково-природознавчого музею АН УРСР, 1958; 5: 50-72.

6. Улична К.О. Мохові синузії у рослинному покриві високогір'я Українських Карпат. В кн.: Конференція по вивченню фрлори і фауни Карпат та прилеглих територій. К.: Видво АН УРСР, 1960.

7. Улична K.О. Рід Dicranella бріофлори УРСР. Наукові записки Львівського науковоприродознавчого музею АН УРСР, 1961; 9: 140-153.

8. Улична К.О. Мохові синузії суміжних асоціацій Mughetum hylocomioso-myrtillosum та Myrtilletum polytrichoso-hylocomiosum на Чорногорі. Український ботанічний журнал, 1961; 18 (1): 58-67.

9. Улична К.О. Мінливість видів роду Dicranum Hedw. Наукові записки Львівського науково-природознавчого музею АН УРСР, 1962; 10: 70-74.

10. Ulyczna K.O. Hepaticae et Musci URSS Exsiccati. Curavit L.I. Savicz-Ljubitzkaja. Л.: Издво AH CCCP, 1961; (12): 4.

11. Ulyczna K.O. Hepaticae et Musci URSS Exsiccati. Curavit L.I. Savicz-Ljubitzkaja. Л.: Издво АН СССР, 1962; (19): 3. 
12. Улична К.О. Річний приріст у висоту стебла рунянки звичайної (Polytrichum commune Hedw.) в рослинних угрупованнях Чорногори. Український ботанічний журнал, 1963; 20 (4): 98-106.

13. Улична К.О. Вік гаметофіта рунянки звичайної (Polytrichum commune Hedw.) та гілокомію блискучого (Hylocomium splendens (Hedw.) Br. Eur.) у рослинних угрупованнях Чорногори. Український ботанічний журнал, 1963; 20 (5): 61-67.

14. Улична К.О. Приріст стебла гілокомія блискучого (Hylocomium splendens (Hedw.) Bryol. Eur.) в рослинних угрупованнях Чорногори. В кн.: Екологія та систематика рослин Карпат і прилеглих територій. К., 1963: 56-63.

15. Улична К.О. Вплив удобрення та заказності на мохове вкриття трав'янистих асоціацій полонин Карпат. В кн.: Рослинність Українських Карпат і шляхи її раціонального використання. К., 1964: 69-76.

16. Улычна К.О., Пилявский Б.Р. Поедание спорогонов мхов мышевидными грызунами. Ботанический журнал, 1965; 50 (11): 1621-1623.

17. Улична К.О. Поширення видів мохоподібних у рослинних угрупованнях Чорногори. Матеріали III з'їзду Українського ботанічного товариства. К.: Наук. думка, 1965: 62-67.

18. Улична К.О. До історії поширення мохоподібних на хребті Чорногора (Українські Карпати). Український ботанічний журнал, 1966; 23 (4): 57-63.

19. Улычна К.О. Апогамные структуры на диплоидных гаметофитах у некоторых мхов из семейства Pottiaceae. Ботанический журнал, 1968; 53 (3): 375-376.

20. Улична К.О. Аномалії при утворенні гаметангіїв у бівалента потії стовбурової (Роttia truncata (Hedw.) Fürnr.). Український ботанічний журнал, 1968; 25 (3): 97-99.

21. Улична K.O. Tayloria serrata (Hedw.) Bryol. Eur. з Українських Карпат. Український ботанічний журнал, 1969; 26 (1): 105-107.

22. Улична К.О. Форми росту мохів Карпатського високогір'я. Матеріали IV з'їзду Українського ботанічного товариства. К., 1969: 239-241.

23. Улична К.О., Партика Л.Я. До бріофлори Чивчинських гір. Український ботанічний журнал, 1970; 27 (1): 25-29.

24. Улична К.О. Форми росту мохів високогір'я Карпат. Український ботанічний журнал, 1970; 27 (2): 189-196.

25. Улычна К.О. Особенности морфогенеза у регенерантов спорогонов мха. Онтогенез, 1971; 2 (2): 207-212.

26. Улична К.О. Pleuroclada albescens (Hook.) Spruce в Українських Карпатах. Український ботанічний журнал, 1971; 28 (2): 227-228.

27. Улична К.О., Партика Л.Я. Рідкісні види бріофлори України та потреби їх охорони. Український ботанічний журнал, 1972; 29 (5): 581-585.

28. Демків О.Т., Улична К.О. Спроба математичного аналізу росту молодої протонеми фунарії вологомірної. В кн.: Шляхи експериментального дослідження морфогенезу вищих рослин. К.: Наук. думка, 1972: 116-123.

29. Улична К.О. Бріоценологічні дослідження у високогір'ї Українських Карпат. В кн.: Дослідження біогеоценозів західних областей УРСР, їх раціональне використання та охорона. К., 1972.

30. Улычна К.О. Моховые синузии и их структура. Тезисы докладов V делегатского съезда Всесоюзного ботанического общества. К., 1973: 193-194.

31. Лазаренко А.С., Улычна К.О. Рецензия на кн.: Савич-Любицкая Л.И., Смирнова З.Н. Определитель листостебельных мхов СССР. Верхоплодные мхи. Л.: Наука, 1970. Ботанический журнал, 1973; 58 (1): 143-144.

32. Улична К.О. Зелігерієві. Поширення, потреба охорони. В кн.: Охорона природи та раціональне використання природних ресурсів у західних областях УРСР. Львів, 1974: 107-108. 
33. Улична К.О. До поширення товстянки двоколірної (Pinquicula bicolor Wol.) на Львівщині. Український ботанічний журнал, 1974; 31 (1): 96-98.

34. Улична К.О. Два нових види для бріофлори України. Український ботанічний журнал, 1974; 31 (5): 653-655.

35. Улычна К.О. Изменчивость листочков у видов рода Atrichum P. Beauv. на протяжении онтогенеза. В кн.: Новости систематики высших и низших растений. Киев, 1974: $171-177$.

36. Улычна К.О. Этапы развития бриофрлоры Украинских Карпат. Тезисы докладов XII Международного ботанического Конгресса. 3-10 июля 1975. Л., 1975; (1): 89.

37. Улычна К.О. Аномальное размещение гаметангиев и проблема происхождения мхов. В Кн.: Флора, систематика и филогения растений. Киев, 1975: 192-194.

38. Демків О.Т., Ріпецький Р.Т., Малиновський К.А., Улична К.О. Андрій Созонтович Лазаренко (до 75-річчя з дня народження). Український ботанічний журнал, 1976; 33 (6): 652-653.

39. Улична К.О. Бріологічний гербарій. Печіночні мохи. В кн.: Каталог музейних фондів. Державний природознавчий музей АН УРСР. К.: Наук. думка, 1976: 57-73.

40. Улична К.О. Мінливість листків мохів протягом онтогенезу. В кн.: Досягнення ботанічної науки на Україні. К.: Наук. думка, 1976: 178-179.

41. Улична К.О. Гібридні спорогони у Phascum cuspidatum Hedw. (Pottiaceae, Musci). Український ботанічний журнал, 1977; 34 (2): 155-158.

42. Улична К.О. Листяні мохи І. В кн.: Каталог музейних фондів. Державний природознавчий музей АН УРСР. К.: Наук. думка, 1978: 5-42.

43. Улична К.О. Листяні мохи ІІ. В кн.: Каталог музейних фондів. Державний природознавчий музей АН УРСР. К.: Наук. думка, 1978: 42-92.

44. Улична К.О. Поширення представників родини Seligeriaceae (Musci) на заході УРСР. Український ботанічний журнал, 1978. 35 (2): 265-269.

45. Улична К.О., Вороніна Н.М. Бріологічний гербарій. Листяні мохи III. В кн.: Каталог музейних фондів. Державний природознавчий музей АН УРСР. К.: Наук. думка, 1979: 4-18.

46. Голубець М.А., Демків О.Т., Ріпецький Р.Т., Улична К.О. Пам'яті Андрія Созонтовича Лазаренка. Український ботанічний журнал, 1980; 37 (2): 76-78.

47. Улична К.О. Динаміка мохових синузій бучин Опілля. Український ботанічний журнал, 1980; 37 (6): 45-48.

48. Федык Я.Д., Улычна К.О., Демкив О.Т. О жизненном цикле мха Tetraphis pellucida (Tetraphidaceae). Ботанический журнал, 1981; 66 (7): 1027-1029.

49. Demkiv O.T., Ripetsky R.T., Fedyk Ja.D., Ulychna K.O. Control of the morphogenetic patterns and the stability of the epigenetic state in bryophytes. Abstract XIII International botanical congress (Sydney, 21-28 August). 1981.

50. Федик Я.Д., Улична К.О. Особливості морфології листостеблових пагонів гаметофріта Tetraphis pellucida Hedw. Український ботанічний журнал, 1982; 39 (1): 47-51.

51. Улычна К.О. Об изменчивости вида Fissidens cristatus Mitt. В кн.: Новости систематики низших растений. 1983; 20: 200-203.

52. Данилкив И.С., Улычна К.О. Анатомо-морфологические особенности видов рода Rhizomnium (Broth.) Kop. В кн.: Материалы VI Закавказской конференции по споровым растениям. Тбилиси, 1983: 134.

53. Улична К.О., Данилків І.С. Анатомо-морфологічні особливості видів роду Rhizomnium (Broth.) Кор. Український ботанічний журнал, 1983; 40 (1): 50-55.

54. Улична К.О., Бондар Т.Г. Рід Rhizomnium (Broth.) Kop. родини Mniaceae в гербарії мохоподібних музею. В кн.: Каталог музейних фондів. Державний природознавчий музей АН УРСР. К.: Наук. думка, 1985: 4-8.

55. Бондар Т.Г., Улична К.О. Матеріали по роду Tortula Hedw., родини Pottiaceae (Musci) бріологічного гербарію музею. 1. Секція Zygotrichia. В кн.: Каталог музейних фондів. Зб. наук. праць. К.: Наук. думка, 1985: 8-14. 
56. Лобачевська О.В., Улична К.О., Демків О.Т. Особливості відновлення і вегетативного розмноження Plagiomnium undulatum (Hedw.) Kop. (Mniaceae, Bryopsida). Український ботанічний журнал, 1986; 43 (3): 30-34.

57. Улычна К.О., Демкив О.Т. Закладка гаметангиев у мхов и аномалии в их образовании. В кн.: Гаметогенез, оплодотворение и эмбриогенез семенных растений, папоротников и мхов. Тез. докл. IX Всесоюзн. совещ. по эмбриологии растений (Кишинев, 1-2 декабря 1986). Кишинев: Штиинца, 1986: 124.

58. Кулик Т.Г., Улична К.О. Матеріали родини Entodontaceae у бріологічному гербарії музею. В кН.: Каталог музейних фондів. Державний природознавчий музей АН УРСР. К.: Наук. думка, 1987: 6-15.

59. Цигель М.С., Кулик Т.Г., Улична К.О. Внутрівидові таксони виду Ceratodon purpureus (Hedw.) Brid. (Musci) у фондах музею. В кн.: Каталог музейних фондів. Державний природознавчий музей АН УРСР. Львів, 1987: 144-153.

60. Партика Л.Я., Улична К.О. Анатомо-морфологічні особливості виду Dicranum muchlenbeckii B.S.G. Український ботанічний журнал, 1987; 44 (1): 49-56.

61. Бачурина Г.Ф., Мельничук В.М. Флора мохів Української РСР. Вип. 1. К.: Наук. думка, 1987. 180 с. (Улична К.О. Родина Дикранові. С. 98-159).

62. Партика Л.Я., Улична К.О. Арктоальпійський елемент бріофрлори Українських Карпат. Український ботанічний журнал, 1988; 40 (3). 48-51.

63. Кулик Т.Г., Улычна К.О. Семейства левкодонтовые (Leucodontaceae) и гукериевые (Hookeriaceae) в бриологическом гербарии музея. В кн.: Биосистематическая структура музейных фондов, Львов. ун-т, Гос. природ. музей АН УССР, Львов, 1989: 63-66. Деп. в ВИНИТИ 13.03.89, № 1634-В89.

64. Улычна К.О., Кулик Т.Г. Материалы по роду родобриум (Rhodobryum) семейства бриевые (Bryaceae) в гербарии мохообразных. В кн.: Биосистематическая структура музейных фондов, Львов. ун-т, Гос. природ. музей АН УССР, Львов, 1989: 50-55. Деп. в ВИНИТИ 13.03.89, № 1634-В89.

65. Улычна К.О., Гапон С.В., Кулык Т.Г. К методике изучения эпифитных моховых обрастаний. В кн.: Проблемы бриологии в СССР. Л.: Наука, 1989: 201-206.

66. Гапон С.В., Улычна К.О. О методах изучения моховых обрастаний. В кн.: Тезисы докладов VII конференции по споровым растениям Средней Азии и Казахстана. Ташкент: Фан, 1989: 185-186.

67. Партика Л.Я., Райці М., Улична К.О. Поширення видів роду Rhodobryum (Schimp.) Limpr. на Україні. Український ботанічний журнал, 1990; 47 (3): 28-31.

68. Хоркавців Я.Д., Улична К.О. Порівняльне дослідження Bryum violaceum Grund et Nyh. i B. klinggraeffii Schimp. (Musci) із заходу УРСР. Український ботанічний журнал, 1990; 47 (3): 32-36.

69. Лобачевська О.В., Улична К.О. Гібридна популяція моху Tortula canescens Mont x T. muralis Hedw. з околиць м. Миколаєва (Львівська обл.). Український ботанічний журнал, 1994; 51 (4): 84-91.

70. Хоркавців Я.Д., Улична К.О. Ризоїдальні бульбочки моху Barbula unquiculata Hedw. (Pottiaceae). Український ботанічний журнал, 1995; 52 (3): 399-404.

71. Lazarenko A.S., Ulychna K.O. Seligeria brevifolia (Musci, Seligeriaceae) new to the Carpathians. Fragm. Flor. Geobot., 1996. 41 (2): 1023-1024.

72. Червона книга України. Рослинний світ. Київ: Укр. енциклопедія, 1996. 608 с. (С. 458, 460, 466, 473, 479, 482, 483).

73. Демків О.Т., Малиновський К.А., Улична К.О., Данилків І.С., Ріпецький Р.Т. Андрій Созонтович Лазаренко (до 100-річчя від дня народження). Український ботанічний журнал, 2001; 58 (6): 768-775. 


\title{
THE $85^{\text {TH }}$ ANNIVERSARY OF KUPAVA O. ULYCHNA
}

\author{
O. V. Lobachevska', Z. I. Mamchur', T. G. Kulyk \\ ${ }^{1}$ Institute of Ecology of the Carpathians NAS of Ukraine, \\ 11, Stefanyk St., Lviv 79000, Ukraine \\ e-mail: morphogenesis@mail.Iviv.ua \\ 2Ivan Franko National University of Lviv, 4, Hrushevskyi St., Lviv 79005, Ukraine \\ ${ }^{3}$ Museum of Natural History NAS of Ukraine, \\ 18, Teatralna St., 79008 Lviv, Ukraine
}

In the article, dedicated to the $85^{\text {th }}$ anniversary of the ukrainian botanist-bryologist Kupava O. Ulychna, biographic materials, the main directions of scientific research activity of the scientist are given and the scientific publications are listed.

Key words: Ulychna Kupava O., bryologist, bryophytes, herbarium, bryoflora of Ukrainian Carpathians, growth forms, moss synusium.

\section{К 85-ЛЕТНЕМУ ЮБИЛЕЮ КУПАВЫ ОСТАПОВНЫ УЛЫЧНОЙ}

\section{О. В. Лобачевская', З. И. Мамчур², Т. Г. Кулик}

${ }^{1}$ Институт экологии Карпат, ул. Стесраника, 11, Львов 79000, Украина

e-mail: morphogenesis@mail.Iviv.ua

${ }^{2}$ Львовский национальный университет имени Ивана Франко ул. Грушевского, 4, Львов 79005, Украина ЗГосударственный природоведческий музей НАН Украины, ул. Театральная, 18, Львов 79008, Украина

В статье, посвященной 85-летию украинского ботаника-бриолога Купавы Остаповны Улычной, приведены биографические материалы, рассмотрены главные направления научно-исследовательской деяльности и представлен список научных работ выдающейся исследовательницы.

Ключевые слова: Улычна Купава Остаповна, бриолог, моховидные, гербарий, бриофлора Украинских Карпат, формы роста, моховые синузии.

Одержано: 15.01.2009 